原

胃癌患者における Su-PS 皮膚反応，Su-PR 皮膚反応について

\author{
東京女子医科大学第二病院外科 \\ 小川智子小川健治矢川裕一 \\ 稲 葉 陖三暒 原哲郎榊原宣
}

免疫療法を有効に行うには，担癌生体の免疫能を正確に把握すると同時に，治療効果 の指標ともなるバラメーターが必要となる.容連菌から抽出されたSu-PSによるSu-PS 皮局反応，これをさらに精製した Su-PRによるSu-PR 皮庙反応がこうした目的にかな 5ものであるかどらか，胃癌患者144症例を対象として険索し，つぎの結果をえた。

1）Su-PS 皮届反応，Su-PR 皮厝反応は，胃癌の進行にともな5患者の免疫能を把握す るパラメーターになりらる.

2）Su-PS 皮席反応は，OK-432に対する胃癌患者の感受性を表わすハランーターであ る.

3） OK-432投与期間中の胃癌患者で Su-PS 皮唐反応の推移をみれぱ，OK-432投与の 治療効果判定の指標となる.

以上より，胃癌患者で Su-PS 皮戌反応，Su-PR 皮店反応を測定することは，その治療 上，意義があることと思われる。

柬引用語：胃癌, Su-PS 皮席反応, Su-PR 皮席反応

はじめに

胃癌に対する治療は外科的手術療法に加えて，化学 療法, 免疫療法などの補助療法が広く行われている。 なかでも免疫療法が注目されているが, 現在一般的に 行われている免疫療法は, 免疫賦活剂により担癌生体 の免疫能を賦活あるいは增強させ，抗腫瘍効果さらに 延命効果をらることを目的とした非特異的免疫療法で ある。

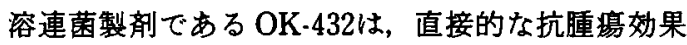
のほかに, 強力な biological response modifier (BRM) 作用を有する免疫賦活剂であり ${ }^{122) ， わ れ わ れ ~}$ むその宿主介在性の抗腫場効果を期待し，皮内による 全身投与を行ってきだ．

そこで，この免疫療法をより有效に行らには，担癌 生体の免疫能を正確に把握すると同時に, 治療効果判 定の指標ともなるパラメーターが必要となる，本稿で は溶連菌から抽出された Su-PSによる皮庙反応（SuPS 皮唐反応)，これをさらに精製した Su-PRによる皮 風反应 (Su-PR 皮席反応) が, 胃癌患者の免疫能を把

昭和 62 年 3 月 6 日受付 62 年 3 月19日採用
握するバラメーターとして有用であるかどらか検索し た.ささらに, OK-432投与期間中, Su-PS 皮席反応を長 期に観察しえた胃癌症例から，本反心が OK-432投与 の治療効果判定の指標となりらるかについても検討し た。

\section{検索対象}

検索対象は1981年より1985年までに当科に入院，手 術をらけた70歳以下の胃癌患者144症例である。胃癌取 扱い規約》による進行程度は, stage Iおよび II 60症 例, stage III 38症例, stage IV 46症例である。

\section{検索方法}

\section{A. 皮店反応}

1. Su-PS 皮席反応

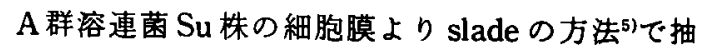
出した多糖体, Su-PS 溶液を $0.1 \mathrm{ml}$ 前腕皮内に注射し, 24 時間後に紅斑の綐, 横径を測定, その平均値を求め, 指標とした。

2. Su-PR 皮后反応

$\mathrm{A}$ 群溶連菌 Su株の細胞膜より Lancefield の方法6) で抽出し，さらに精製した Su-PR 溶液を $0.1 \mathrm{ml}$ 前腕皮 内に注射し，24時間後に紅斑の綐，横径を測定，その 


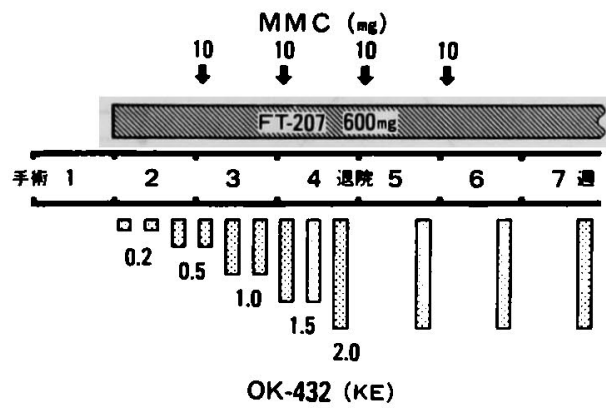

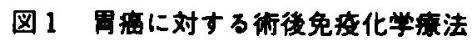

平均値を求め, 指標とした。

\section{PPD 皮席反応}

日本 BCG 製造株式会社製の一般診断用精製ッベル クリン $(0.5 \mathrm{ng} / \mathrm{ml})$ を $0.1 \mathrm{ml}$ 前腕皮内に注射し，48時 間後に紅班の縦，横径を測定，その平均値を求め，指 標とした。

\section{B. 免疫化学療法}

胃癌術後における免疫化学療法は図 1 のごとく施行 した，免疫療法にはOK·432を，化学療法には Mitomycin C, Tegafur を使用し，投与は手術の影墼 で低下した免疫能が回復する術後第 2 週より開始し た.

\section{検索成績}

\section{A. 胃癌進行程度別にみた皮有反応}

胃癌進行程度別にみた Su-PS, Su-PR 皮席反応の測 定値は图 2 に示すとおりである.

\section{Su-PS 皮后反応}

Su-PS 皮庙反応と進行程度との関係は, stage I-II で12.6, stage III で10.1, stage IVで7.2となり, 進 行にしたがい低下した. stage I・II と stage IV の間で 有意差を認めた $(\mathrm{p}<0.05)$.

2. Su-PR 皮席反応

Su-PR 皮届反応と進行程度との関保は, stage I ・ II で12.8, stage III で7.2, stage IVで6.5となり, 進行 にしたがい低下した. stage I•II と stage III, stage I• II と stage IV の間で有意差を認めた（ $p<0.05 ）$.

\section{B. OK-432投与と Su-PS 皮席反応}

1. OK-432投与に対する Su-PS 皮居反応の反応性 免疫化学療法施行例で, 術前から術後 (OK-432総量 30KE 投与時)にわたる Su-PS 皮店反応，PPD 皮庞反 応の変動は图 3 に示すとおりである.Su-PS 皮用反応 は增強している症例が多かったのに対し, PPD 皮底反 応は一定の傾向を示さなかった。

\section{Su-PS}

Su-PR
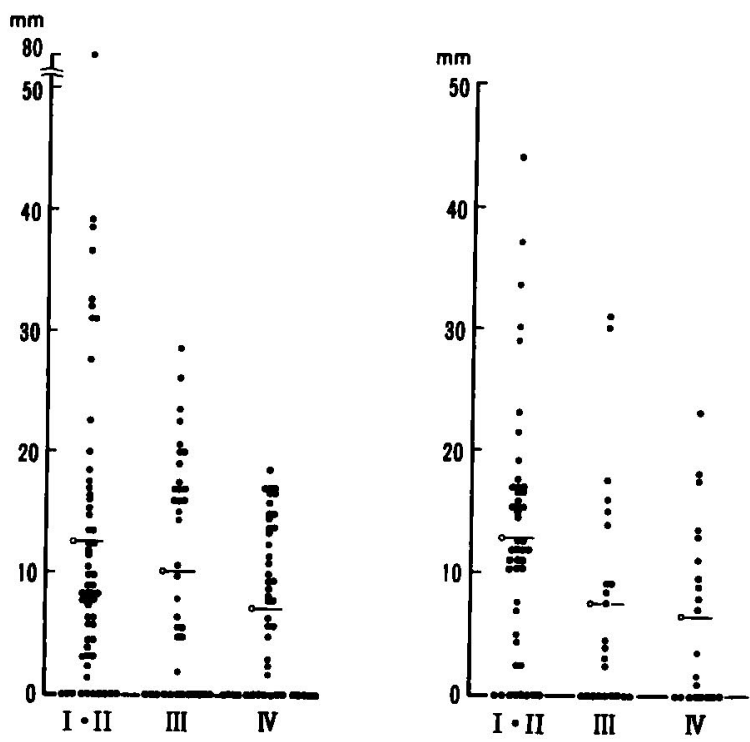

图2 胃雷集行程度別にみたSu-PS, Su-PR 皮庙反応
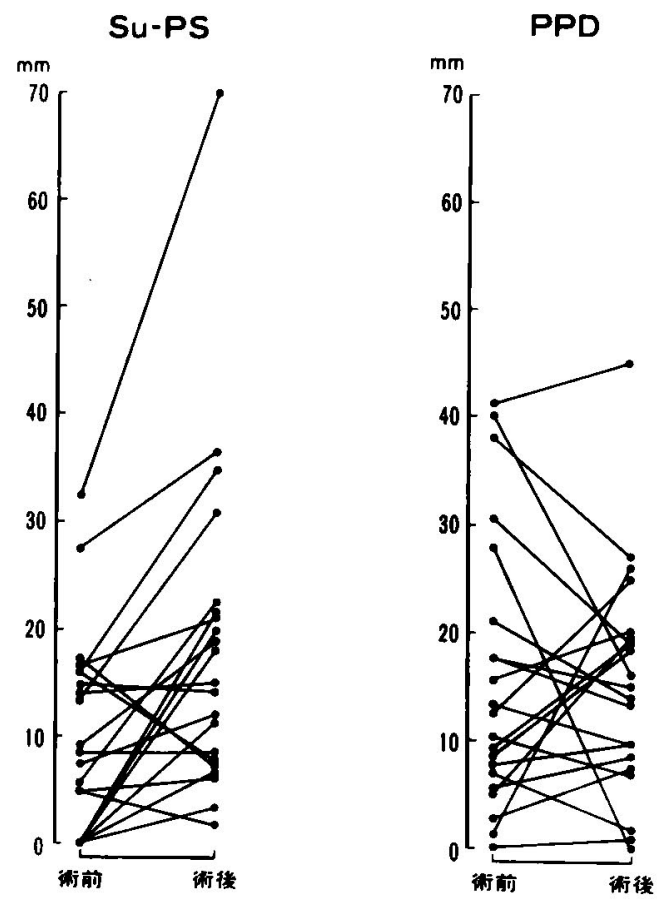

图 3 OK-432投与例における Su-PS, PPD 皮唐反応 の術前後の变勤

2. 胃癌進行程度別にみたSu-PS 皮庙反応の推移 免疫化学療法施行例で，胃癌の進行程度別に OK432投与期間中の Su-PS 皮席反応の推移をみた. 
stage I・II は全例生存例で, 経時的変動はあるが術 後増強している症例がほとんどであった(図 4). stage III では，生存例では術前値と同じような值をとるか， 很後增強がみられた，死亡例では早い時期に低下する むの，一時増強しても死亡前に低下寸るものがみられ た(図 5 ). stage IVでは，切除生存例では比較的術前 値と同じうな値で推移するものが多かった。切除死 亡例，非切除死亡例では早い時期に低下するるのがほ とんどであった（図6）.

3. 症例

Su-PS 皮席反応と胃癌の臨床経過との関係を症例

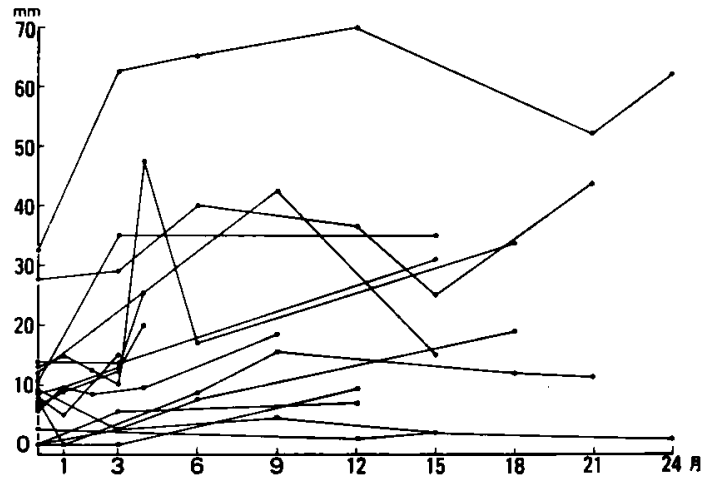

图 4 stage I ・II 症例における Su-PS 皮虚反応の推移

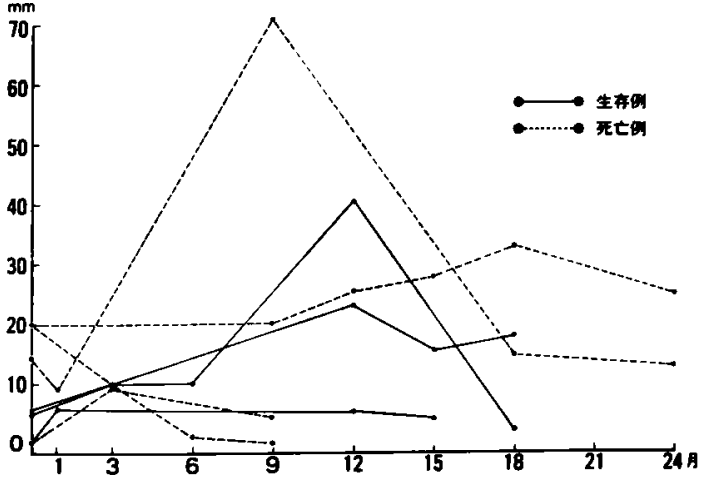

图 5 stage III 症例における Su-PS 皮庙反応の推移

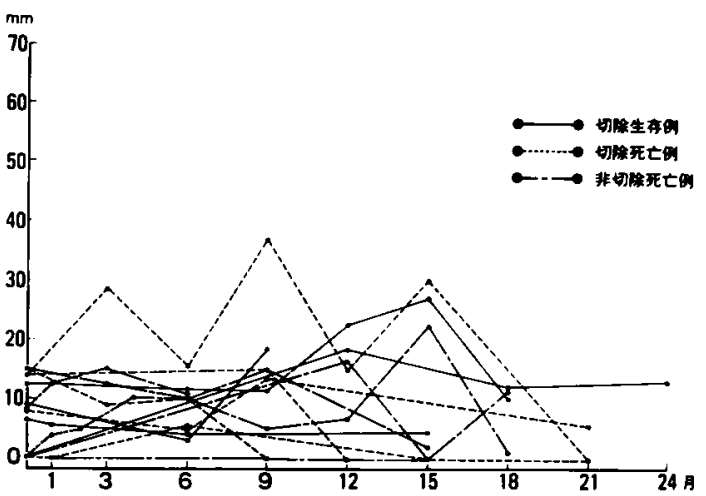

因 6 stage IV 症例における Su-PS 皮庙反応の推移

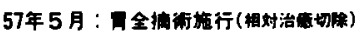

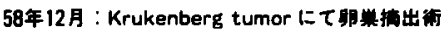

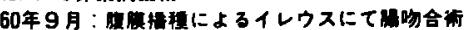

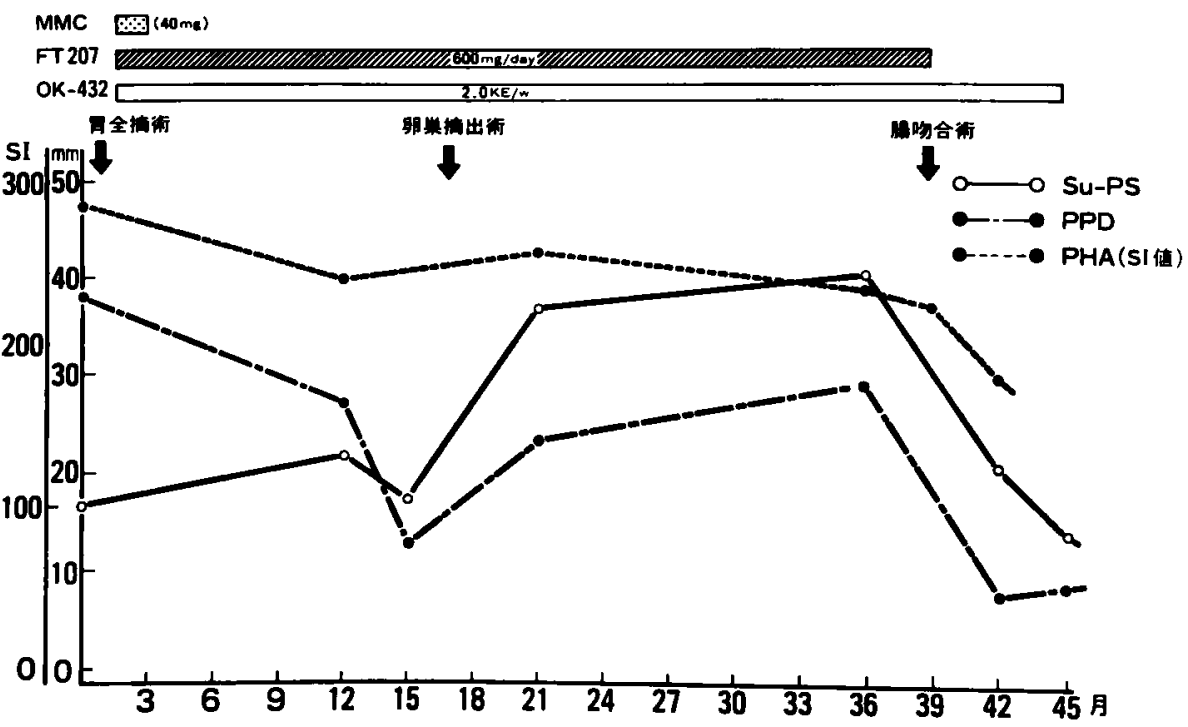

图 7 症例：S.H. 33葴女性 MK (Borr III) stage III $\left(\mathrm{PoHon}_{2} \mathrm{se}\right)$ 
で提示する(図 7)，症例は33歳，女性，Borrmann III 型胃癌で胃全摘術兼腪脾合併切除術 ( $\mathrm{R}_{2}$ 郭清)を施行. $\mathrm{P}_{0}, \mathrm{H}_{0}, \mathrm{n}_{2}(+)$, se, stage III, 病理組織型は poorly differenciated adenocarcinoma であり,術後は免度化 学療法を施行した.Su-PS 皮庙反応は, Krukenberg 腫 埸が出現した術後19カ月前には低下を示したが，その 腫掝摘出後，反応は増強した。しかし，癌性腹膜炎を 併発した術後39力月前には再び低下した。そ後は増 強を示さず，全身状態は悪化して術後45力月で死亡し た. 他のパラメーターをみると, PPD 皮底反応は Krukenberg 腫場出現時にはSu-PS 皮席反応と同じょう に低下したか，死亡前にやや增強した。 PHA (SI 値) は術前值と同じょらな値を維持していたが，死亡前に 低下した。

\section{考察}

近年, 胃癌に対する治療は外科的手術療法に加之て, 種々の補助療法が行われている。なかでも免疫療法は 注目され, われわれも現在, 胃癌手術後に免疫化学療 法を行っている.溶連菌製剂 OK-432による免度療法 と Mitomycin C, Tegafurによる化学療法を組み合わ せたもので, 遠隔成績からみて stage III を中心に治療 奻果を認めている゙!。 このよらな免疫療法を主体とし た補助療法をより有効に行うには，担癌生体の免度能 を正確に把握すると同時に，治療効果判定の指標とも なるバラメーターが必要となる.

そこでまず,Su-PS 皮唐反応拉よび Su-PR 皮席反応 か，胃癌患者の免疫能を把握するパラメーターとして 有効であるかどうか検索した。ささらに Su-PS 皮店反応 の推移を長期に観察しえた胃癌症例から，Su-PS 皮庯 反応が OK-432投与の治療効果判定の指標となりらる かについて検討した。

Su-PS 皮庙反応は，A群溶連菌 Su株よりえられた 多糖体による反応である。胃癌の進行程度との関係で は, stageが進むにしたがい反応は低下した。すずに, 本反応は胃癌の進行にしたがって低下すること，しか もそれはPPD 皮庙反応，末梢血リンバ球数，末梢血り ン八球 PHA 幼若化反応などと平行した動きをするこ となどを報告》しているが，今回の対象症例を増やし ての検索であ同じ成樍であった. Su-PS 皮凩反応は, 胃癌の進行にともなら患者の免疫能の変動をよく反映 しており，胃癌患者の免疫能をしるパラメーターとし て有用であると考えられる。

Su-PR 皮庙反応は, Su-PSをさらに精製して作られ た Su-PR による反応である.この Su-PR には，免度反
応の主体をなす蛋白質が約 $98 \%$ 含まれているといわれ ている゙．胃癌の進行程度との関係では, stage が進む にしたがい反応は低下して扔り，Su-PS 皮席反応と同 じょ5に患者の免疫能をよく反映していた. Su-PR 皮 府反応と胃癌の進行程度との関係をみた報告はない が, 本反応る胃癌患者の免疫能をしるパラメーターに なりらると考えられる。

つぎに，OK-432投与に対するSu-PS 皮届反応の反 応性をみるため, OK-432総量 $30 \mathrm{KE}$ 投与前後にわたる Su-PS 皮席反応の変動をPPD 皮展反応を対照にみ た、Su-PS 皮唐反応は明らかに増強している症例が多 かったのに対し，PPD皮府反応は一定の傾向を示さ ず，春日らのの，OK-432投与後に Su-PS 皮薄反応は増 強したか，PPD，PHA 皮席反応に増強はみられなかっ たとする報告に一致した成績であった。すなわち，OK432に対する感受性が胃癌患者にあり，その投与が免疫 機構に何らかの影橥を与えるならぱ，それに反応して Su-PS 皮庙反応が変動するものと考えられる.Su-PS 皮局反応は，OK-432に対する感受性を表わすパラメー ターであると思われる。

さらに,この Su-PS 皮庙反応の動きを胃癌の進行程 度別にみた. stage I・II では, 術後増強している症例 がはとんと゚であり， stage III では術前値と同じょうな 値をとるか増強する症例，術後低下寸る症例とに分か れた。 また， stage IVでは術前値と同じような值をと る症例も少数例はみられるが, 多くは術後早期より低 下した. 寸なわち, stage I ・II といった比較的早期の 症例, stage III でも術後経過良好な生存例では, Su-PS 皮庙反応は増強または不変であった。このような症例 はOK-432に対する感受性が高いことが示唆され，良 好な治療成績が期待されるるのが多かった。他方, stage III でも再発, 死亡した症例, stage IV の切除死 亡例, 非切除死亡例では, Su-PS 皮度反応は術後低下 し，とくに死亡前はほとんどの症例で低下した。この よらな症例は OK-432に対する感受性は低いと考えら れ，その治療成績も不良であった。 花上ら ${ }^{101}$ は, Su-PS 皮庙反応は担癌生体の OK-432に上る感作の程度を知 るだけでなく, 細胞性免度能の把握, 予後の判定など にも臨床上優れたバラメーターであることを報告して いる.さらに渡辺ら ${ }^{11}$ む，Su-PS 皮屈反応の成績と患 者の予後との間には密接な相関がみられるとし, 長期 の OK-432㞠法によっても本反応が陰性を持続するも のや陽性から陰性に転じたものの予後は明らかに不良 であること，逆に，陽性を維持するわのの予後はきわ 
めて良好であることを報告している，われわれの成績 にこのような報告を考㐫併せれば，Su-PS 皮虐反応 は，胃癌患者の予後を予測する指標になりらると考え られる．提示した症例についても，手術によって癌巣 が完全に切除された時期にはSu-PS 皮庮反応は增強 し，再発，死亡にいたる時期には低下している。この 症例でみるように, Su-PS 皮届反応は，PPD 皮庙反応 やPHA（SI 值）など他のハララーターより臨床経過 をよく反映するように思われる。すなわち，OK-432投 与期間中の胃癌患者で Su-PS 皮府反応の推移をみれ ば，治療効果や予後などが推定できると考えられ，本 反応は OK-432投与の治療効果判定の指標となりらる と思われる。

おわりに

胃癌患者144症例を対象に Su-PS 皮唐反応, Su-PR 皮席反応を検索し，つぎの結果をえた。

1) Su-PS 皮庙反応, Su-PR 皮居反応は, 胃癌の進行 にともなら患者の免废能を把握するバラィーターにな りうる.

2）Su-PS 皮席反応は，OK-432に対する胃癌患者の 感受性を表わすバラメーターである。

3）OK-432投与期間中の胃癌患者で Su-PS 皮庯反 応の推移をみれば, OK-432投与の治療効果判定の指標 となる.

本論文の要旨は第27回日本消化器外科学会総会で報告し た.

$$
\text { 文献 }
$$

1) Hoshino T, Uchida A: OK.432 (picibanil) :
Property, action and clinical effectiveness. Excerpta Medica, 3-12, 1984

2) Nakazato $H$, Yamamura $Y$, Yasue M: Clinical results of chemoimmunotherapy combind with surgical therapy for gastric cancer: An effort to seek out effective combined modality therapy. Excerpta Medica, 245-258, 1984

3) Yagawa H, Ogawa K, Otani Y: Immunochemiotherapy for gast ric cancer affer surgical treatment. Excerpta Medica, 290-299, 1984

4) 胃癌研究会編：外科・病理, 胃癌取扱い規約. 第11 版, 金原出版, 東京, 1985

5) Hutton SD: Extraction of Cell-mall polysaccaride antigen from streptococci. J Bacteriol $90: 667-672,1965$

6) Rebecca LC, Gertrude PE: Preparation and properties of typespecific $M$ antigen isolated friom A group A, type 1 hemolytic streptococcus. J Exp Med $96: 71-82,1952$

7) 小川智子, 矢川裕一, 小川健治他：胃癌患者におけ る Su-PS 皮庙夫応の有用性について，癌と化療 $11: 2221-2226,1984$

8）金子幸夫, 羽場文彦, 田中剖史他：溶連菌製剂 OK432 の Su-PR 皮内反応の有用性についての検討, 臨と研 $63: 276-280 ， 1986$

9）春日正己，咲田雅一，土井正樹他：OK-432に対寸 る宿主夫応性とその効果について, 日消外会誌 $17: 1587-1594,1984$

10）花上 仁, 野本信之助, 吉崎 聰：癌免疫療法にお ける免疫学的ハランーターと予啳について，日消 外会誌 $16: 1374-1379,1983$

11）渡辺洋宇，山田哲司，小林弘明他：OK-432に上る 免疫療法に際しての Su・ボリサッカーライド皮庙 夫応の意義, 癌と化㞠 $8: 1076-1083,1981$

\title{
THE USEFULNESS OF THE Su-PS AND Su-PR SKIN REACTION TEST FOR GASTRIC CANCER PATIENTS
}

\author{
Tomoko OGAWA, Kenji OGAWA, Hirokazu YAGAWA, Syunzo INABA, \\ Tetsuro KAJIWARA and Noburu SAKAKIBARA \\ Department of Surgery, Tokyo Women's Medical College Daini Hospital
}

The Su-PS and Su-PR skin reaction was determined in 144 patients with gastric cancer, and the following results were obtained.

1) The Su-PS and Su-PR skin reaction was found to be a possible parameter for determination of immunological competence accompanying the advance of gastric cancer.

2) The Su-PS skin reaction was a parameter representing the sensitivity of gastric cancer patients to OK-432.

3) Changes in the Su-PS skin reaction provided an index for evaluating the therapeutic effects of OK-432 administration in patients with gastric cancer.

These results suggest that the Su-PS and Su-PR skin reaction tests are important in the treatment of patients with gastric cancer. 